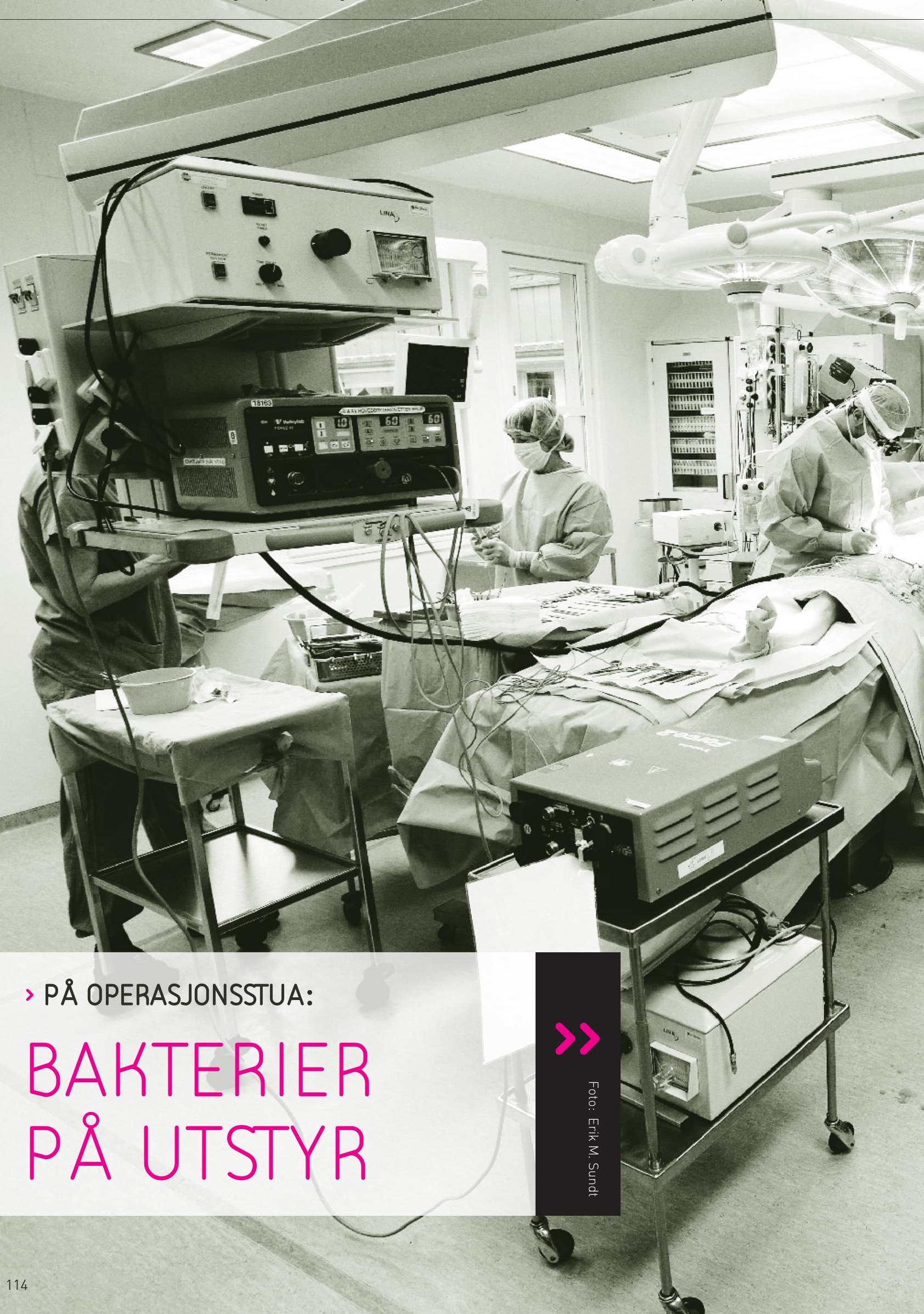




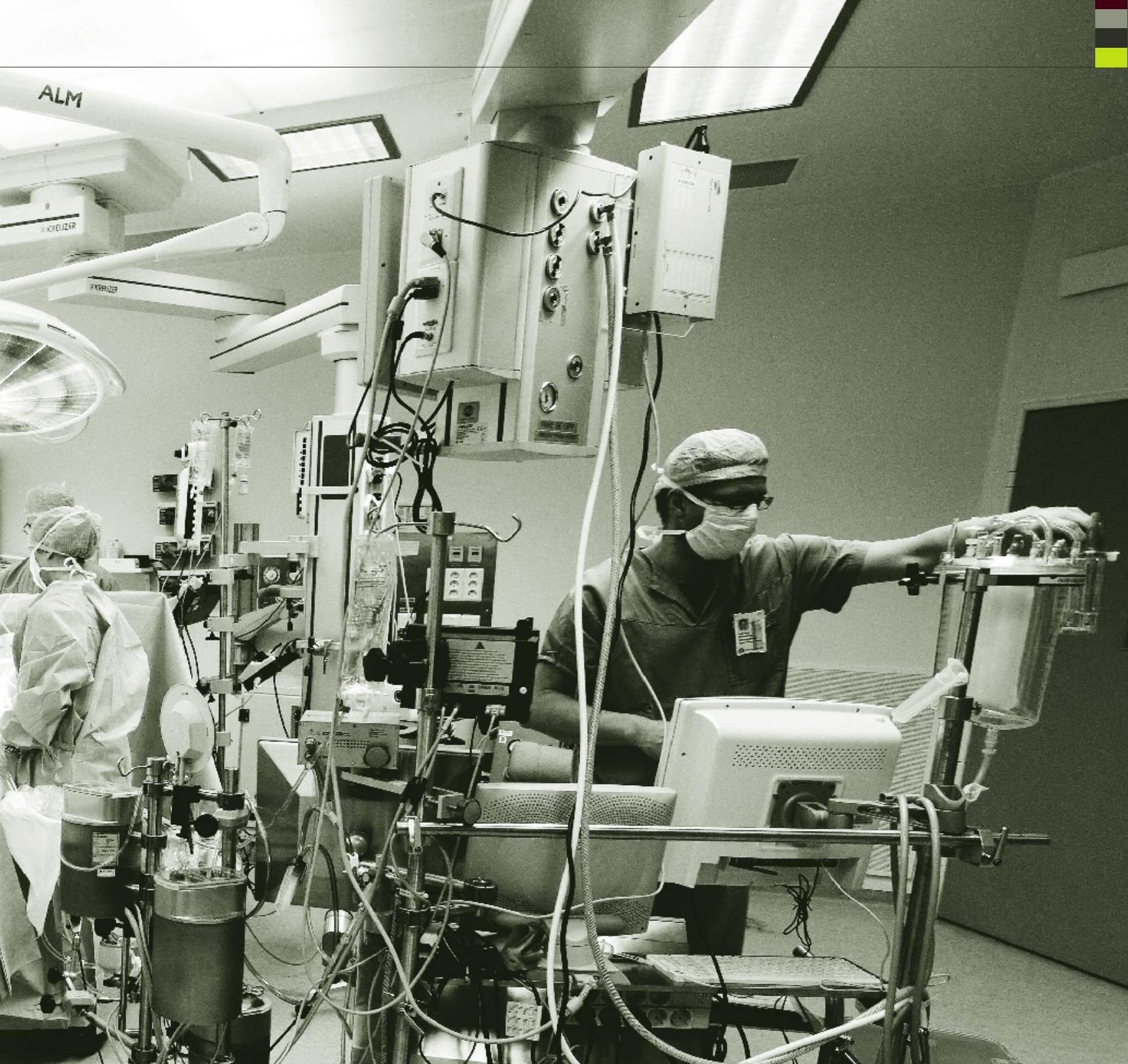



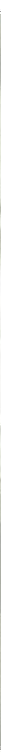

Bakgrunn: Mellom 6-10 prosent av pasientene ved norske sykehus får sykehusinfeksjon, det vil si $60000-100$ 000 tilfeller hvert år. Dette kan få store konsekvenser både for den berørte pasienten og samfunnsøkonomien. Et sentralt tiltak for å unngå at smitteoverføring skjer, er å tilstrebe at utstyr som blir brukt i arbeidet med pasienter på sykehus, har færrest mulig sykdomsfremkallende mikrober.

Hensikt: Målet med studien var å undersøke om mobilt medisinsk teknisk utstyr som står lagret i korridor har større forekomst av mikrober enn utstyr som blir stående inne på operasjonsstuene mellom hver gang de brukes. I tillegg skulle man måle om det var ulik grad av infisering på ulike punkter og høydenivå av apparatene.

Metode: En prospektiv, deskriptiv studie med registrering og måling av ulik grad av infisering på ulike punkter og høydenivå av medisinsk teknisk utstyr. Prøvetakingen ble utført fortløpende i løpet av fem uker, og til sammen ble det tatt 400 prøver.

Resultat: Mikrobetall målt på utstyr lagret utenfor stuene viste en tendens til å være lavere enn på utstyr oppbevart inne på stuene. Mengde oppvekst var størst fra prøver tatt av flater lengst ned mot gulvnivå og på baksiden av apparatene. Prøver som ble tatt fra av/på brytere viste liten grad av bakterieoppvekst. Resultatet fra prøvene tatt av det mobile utstyret viste generelt liten forekomst av bakterier.

Konklusjon: Resultatene oppfordrer til en bevisstgjøring rundt rengjøring og plassering av mobilt medisinsk teknisk utstyr og tilbehør. Det er viktig at det med jevne tidsintervall foretas en slik prøvetaking. Ved de fleste sykehus finnes ikke slike rutiner. Vi mener at denne studien har bidratt til mer kunnskap om kontaminering av mobilt medisinteknisk utstyr brukt ved kirurgiske inngrep.
Bacterial investigations of mobile electro-medical equipment used in operating rooms

Background: Between 6 and $10 \%$ of the patients at Norwegian hospitals. or between 60,000 and 100,000 are getting nosocomial infection. This could have significant consequences for the individual patient as well as for the health economy in general. An important measure to minimize contamination is to reduce the number of pathogenic micro-organisms on equipment used in patient-orientated activity at the hospitals.

Purpose: The purpose of this investigation was to study whether mobile electro-medical equipment stored in the hospital corridor contained more micro-organisms than similar equipment which had been stored in the operating rooms (OR) when not in use. In addition, we wanted to investigate whether bacterial contamination varied on different locations at the equipment, including various levels from the floor.

Method: This is a prospective study which included recording of bacterial contamination at various locations on electro-medical equipment, including different levels from the floor. The tests were taken consecutively during a five-week period from 27 October 2008 and, altogether, 400 bacterial cultures were made.

Result: There was a tendency that the number of micro-organisms on equipment stored outside the OR was lower than on similar equipment stored inside the OR. Contamination was highest at the level closest to the floor and on the back side of the equipment. Samples from the on/off switches showed only minimal contamination. In general, the bacterial contamination of mobile electro-medical equipment was low.

Conclusion: The results indicate that one should be more conscious about cleaning and storage of mobile medical equipment. It seems justified to conduct bacterial investigations with certain time intervals. Most hospitals do not have such routines today. The investigation has provided knowledge about bacterial contamination of electro-medical equipment used during surgical procedures. 


\section{Bakteriologisk provetaking av mobilt medisinsk teknisk utstyr som benyttes på operasjonsstuer}

Forfattere: Augusta Irene Kvam, Jenny Aasland, Jan Gunnar Skogås og Anne Karin Wik

\section{NøKKELORD}

- Operasjon

- Medisinsk-teknisk utstyr

- Bakterie

\section{BAKGRUNN}

Nosokomiale infeksjoner (sykehusinfeksjoner) er et stort problem (1). Mellom 6-10 prosent av pasientene ved norske sykehus får sykehusinfeksjon, det vil si 60 000-100 000 tilfeller hvert år (1). Dette kan medføre store konsekvenser både for den berørte pasienten og samfunnsøkonomien. For pasienten kan det føre til komplikasjoner og forlenget sykehusopphold, i enkelte tilfelle uførhet og i verste fall død $(1,2)$. Sykehusinfeksjoner koster det norske samfunnet mellom 500-1000 millioner kroner årlig (1). Et sentralt tiltak for å bryte smitteveier er å sørge for at utstyr som blir brukt $i$ arbeidet med pasienter på sykehus, er fritt for sykdomsfremkallende mikrober
(3). De fire hyppigste sykehusinfeksjonene er postoperative sårinfeksjoner, urinveisinfeksjoner, lungebetennelser og infeksjoner i blodbanen $(3,4)$. Forebygging av nosokomiale infeksjoner er derfor viktig $(2,3,5)$.

I dagens operasjonsstuer blir det benyttet mye medisinsk teknisk utstyr som kan bli kontaminert av mikrober. Bare den delen av utstyret som er i kontakt med operasjonsfeltet blir sterilisert før bruk. Det øvrige pasientnære utstyret blir vasket eller desinfisert mellom operasjonene $(1,5)$. Apparatenes utforming, plassering av apparater i rack (fig. 1) samt brytere, håndtak og ledninger vanskeliggjør vanlig rengjøring. Samtidig bør ikke utstyret utsettes for mye fuktighet. Utstyret kommer som regel direkte eller indirekte i kontakt med organisk materiale og potensielle smittestoff i forbindelse med operasjoner. Dette kan medføre smittefare for pasienter og personell dersom det ikke er tilstrekkelig rengjort (1). Etter rengjøring blir apparater enten stående inne på operasjonsstuen, plassert i korridor eller på lager. Ut fra hygi- enemessige aspekter, anbefales det ikke å lagre unødvendig utstyr inne på en operasjonsstue (1). Utstyr som oppbevares utenfor stuene, blir ikke vasket eller desinfisert før neste gang de benyttes. Eventuelle mikroorganismer på slike apparater kan dermed bli værende på utstyret.

\section{Hva tilfører denne artikkelen?}

Funnene i artikkelen viser at mobilt medisinsk teknisk utstyr oppbevart i korridor, ikke var mer utsatt for bakterier enn tilsvarende stasjonært utstyr. Undersøkelsen viste også at mengde bakterieoppvekst var størst fra prøver tatt av flater nederst mot gulvnivå og på baksiden av apparatene.

\section{Mer om forfatterne:}

Augusta Irene Kvam er 1.-amanuensis og bioingeniør og ansatt ved Bioingeniørutdanningen, $\mathrm{H} \varnothing \mathrm{g}$ skolen i $\varnothing \varnothing$-Trøndelag. Jenny Aasland er hygienesykepleier og MSc ved St. Olavs Hospital, Seksjon for sykehushygiene. Jan Gunnar Skogås er medisinsk teknisk ingeniør og daglig leder. Anne Karin Wik er operasjonssykepleier. Begge arbeider i Fremtidens operasjonsrom.

Kontakt: augusta.kvamahist.no 
Man tilstreber at medisinsk teknisk utstyr som skal brukes ved kirurgiske inngrep er mest mulig fri for mikrober. Derfor bør ikke lagerrom brukes som kontor/oppholdsrom eller være et lager for urene artikler (1). Studier viser at det blir samlet mest støv ned mot gulvnivå. Støvet kan virvles opp under operasjoner og medføre en viss smittefare (6). Mikroorganismer i støv ned mot gulvet har ikke hygienemessig så store konsekvenser som kontaminerte punkter som berøres med hender mens utstyret er i bruk. Slike steder er mer potensiell smittekilde der bakterier kan overføres til personell og pasienter.

Kolonisering av mikroorganismer på apparater plassert i operasjonsrom, korridorer eller andre lagringsplasser, vil stort sett være forårsaket av luftbåren smitte fra mennesker (7). Hudpartikler som utskilles fra både personalet og pasienter, kan inneholde bakterier som kan sedimentere på apparater. De vanligste hudbakterier er hvite stafylokokker, difteroider og propionbakterier. Men også gule stafylokokker kan forekomme. Staphylococcus aureus (gule stafylokokker), Escherichia coli og ulike typer Klebsiella er de vanligste bakterier som identifiseres ved sykehusinfeksjoner. Hvite stafylokokker regnes ikke som spesielt patogene, men ved for eksempel protesekirurgi og hos pasienter med nedsatt immunforsvar kan disse være årsak til sykehusinfeksjon $(1,8)$.

Det stilles strenge krav til ventilasjonen i en operasjonsstue $(4,9)$. Det skal være overtrykk inne i operasjonsstuen i forhold til tilstøtende rom. Det er viktig å tilstrebe lavest mulig mikrobetall i luften (10). Statens helsetilsyn har anbefalt verdier for mikro- beforekomst i luft benevnt med Colony Forming Units (CFU) / $\mathrm{m}^{3}$, som beskriver antall mikrobebærende partikler /1000 1 luft. Bakterietall i luft angis i CFU $/ \mathrm{m}^{3}$ mens på flater angis dette $\mathrm{i} \mathrm{CFU} /$ $\mathrm{cm}^{2}$ (9). Anbefalt renhet for luft i stuer med spesiell infeksjonsfølsom kirurgi som for eksempel protesekirurgi og nevrokirurgi, er mindre enn $10 \mathrm{CFU} / \mathrm{m}^{3}$. I stuer med generell kirurgi anbefales mindre enn $100 \mathrm{CFU} / \mathrm{m}^{3}$. Statens helsetilsyn gir ingen anbefalinger i forhold til temperatur, luftfuktighet og antall luftskiftninger per time i operasjonsrom $(1,11)$. Ulike faktorer kan ha betydning for luftkvaliteten og mikrobetall i operasjonsstuer. Dette påvirkes først og fremst av antall personer til stede, deres bekledning og

aktivitet $(10,12,13,14)$. I tillegg vil plassering av operasjonsbord, instrumentbord og annet utstyr i forhold til ventilasjon være viktig (6). Alle disse faktorene kan også påvirke luftmålinger som utføres $(9,12)$.

Det er stort fokus på luftkvalitet med hensyn til mikrobiologisk forekomst, derimot er mikrobiologisk prøvetaking av medisinsk utstyr lite beskrevet. I det norske lovverket beskrives ingen krav til renhet på flater i operasjonsstuer eller på overflater på medisinsk teknisk utstyr. De retningslinjer som finnes, er krav for renhet i matindustrien, der renhet på flater er fastsatt $(14,16)$. Dette benevnes som $\mathrm{CFU} / \mathrm{cm}^{2}$ der $<1 \mathrm{CFU} / \mathrm{cm}^{2}=$ eksellent, $2-10 \mathrm{CFU} / \mathrm{cm}^{2}$ = god,
FIGUR 1: Endoskopirack med skisse over prøvetakingspunkter

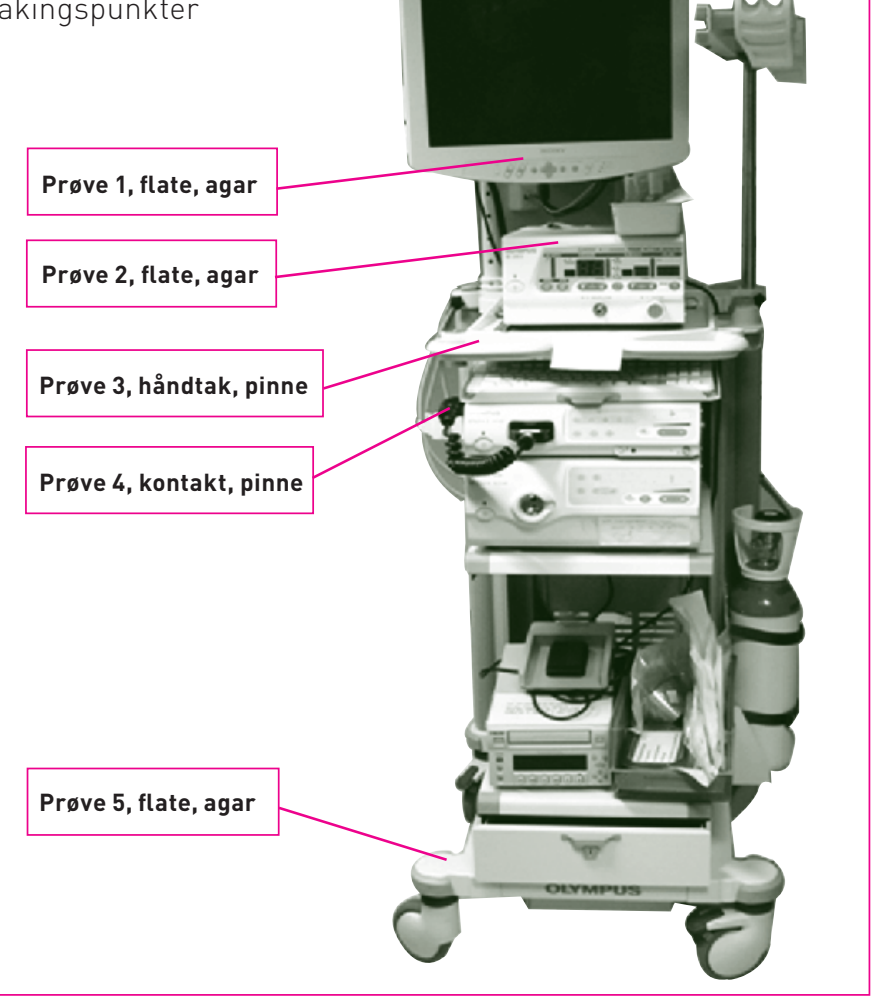


11-100 $\mathrm{CFU} / \mathrm{cm}^{2}=$ overflaten må rengjøres straks, > $100 \mathrm{CFU/}$ $\mathrm{cm}^{2}=$ produksjonen stoppes.

Kartlegging av mikrobiologisk kontaminasjon på mobilt medisinsk teknisk utstyr og på overflater i operasjonsarealer vil derfor være viktig med tanke på infeksjonsforebyggende tiltak i sykehus, og det vil bidra til å øke kunnskapen rundt temaet, noe som gjør dette studiet relevant.

Hensikten med dette prosjektet var å undersøke om mobilt medisinsk teknisk utstyr som står lagret i korridor, har større forekomst av mikrober enn utstyr som blir stående inne på operasjonsstuene mellom hver gang det brukes. I tillegg skulle det måles om det var ulik kontaminasjon på ulike punkter og høydenivå av apparatene.

\section{MATERIALE OG METODE}

Dette var en prospektiv, deskriptiv studie der det ble tatt mikrobiologiske prøver av til sammen åtte enheter med mobilt medisinsk teknisk utstyr som benyttes ved kirurgiske inngrep. Enhetene flyttes mellom de forskjellige operasjonsstuene eller lagringsplasser, alt etter behov.

Utstyret som det ble tatt prøver av, er videre i denne studien benevnt med nummer fra 1-8 (se tabell 1): Tre ultralydgeneratorer (nr. 1, 2, 3), tre endoskopirack (nr. 4, 5, 8), og to diatermiapparat (av ulik utforming) (nr. 6 og 7).

Apparat 1, 2 og 3 er sammenlignbare med hensyn til prøvetakingspunkter og oppbevaringssted. Det samme gjelder apparat 4, 5 og 8, samt apparat 6 og 7.

På hver at de åtte enhetene, ble det for hver prøvetaking tatt fem mikrobiologiske punktprøver. Det ble tatt prøver to ganger per uke, kontinuerlig i fem uker, totalt 400 prøver. Dager for prøvetaking var fastsatt på forhånd og prøvetakingene ble utført kl. 07.00, før daglig aktivitet hadde startet. Alle prøver ble tatt og undersøkt av en og samme person. For å kvalitetssikre at prøver ble tatt fra samme plass ved hver måling, ble bilder av apparatene med markerte prøvepunkter benyttet. På alle apparatene ble prøvepunktene
$\left(\mathrm{CFU} / \mathrm{cm}^{2}\right)$ som vokser opp vil være et mål på renhetsgraden på testet flate. Denne agaren er anbefalt brukt for å sjekke kritiske kontrollpunkter ved etablering eller oppdatering av rutiner for mikrobiell overflatekontroll i sykehus, industri med mer. Count-Tactagar er hensiktsmessig metode på glatte flater.

På ujevne underlag som på brytere, håndtak og kontakter

\section{$\int$ Resultatene viste mer oppvekst fra prover fra baksiden av apparatene enn fra forsiden.}

fordelt på en slik måte at resultatene fra de åtte enhetene kunne sammenlignes (fig. 1). Avstanden fra gulv til prøvetakingspunkt ble beskrevet som øvre og nedre nivå. Nedre nivå ble i dette studiet definert som under $30 \mathrm{~cm}$ og øvre flater definert som over dette nivået. Fra øvre flater på apparat 1,2 og 3 ble det tatt prøver fra både fremre og bakre del av apparatet. Forflytning og brukshyppighet av hvert apparat ble registrert i prøvetakingsperioden.

Metoder som ble brukt til prøvetaking i dette prosjektet var Count-Tactagar og bomullspinner (Plain Swabs F150CA, Sterilin $\left.{ }^{\circledR}\right)$. Count-Tactagar (BIOMÉRIEUX®) er små agarskåler med diameter på $55 \mathrm{~mm}$. Agarflaten settes ned på prøveområdet med et lett trykk i ti sekunder og deretter settes lokket på (10). Agaren inneholder nødvendige næringsstoffer for forventet bakterie- og soppfunn. I tillegg har den fire nøytraliserende agens som inaktiverer eventuelle rester av desinfiserende stoffer på overflater som skal testes. Prøver tatt med denne type agar er en kvantitativ metode, der antall kolonier ble bomullspinner benyttet. Sterile bomullspinner ble på forhånd fuktet med sterilt vann og strøket kontinuerlig fram og tilbake på prøvetakingsstedet. Materialet på pinnen ble deretter avsatt direkte på en blodagar ved å stryke pinnen jevnt utover dyrkningsagaren. Dyrkingsagarer fra begge prøvetakingsmetoder ble satt i plastpose i varmeskap hvor de ble dyrket i $30{ }^{\circ} \mathrm{C}$ i tre døgn, deretter i romtemperatur i fire døgn før oppveksten av bakterier ble registrert. På hver av de åtte enhetene ble det på hver prøverunde tatt tre prøver med agarskåler og to prøver med bomullspinne. Dataene ble satt inn i Microsoft Excel, og det ble utført deskriptive frekvensanalyser.

\section{RESULTATER}

Resultatene fra de mikrobiologiske prøvene, tatt av det medisinsk tekniske utstyret som ble benyttet på operasjonsstuene, viste generelt sparsom oppvekst av bakterier. På de fleste prøver ble det funnet ulike typer hvite stafylokokker. I noen prøver var det sparsomt med ulike 
TABELL 1: Bakterievekst ved prøvetaking av medisinsk teknisk utstyr, oppgitt i median (range). Oppvekst på flater er angitt i CFU/cm2. Oppvekst på håndtak/brytere er angitt i antall kolonier * bakside av apparat

\begin{tabular}{|c|c|c|c|c|c|c|c|c|}
\hline $\begin{array}{l}\text { Oppbevarings- } \\
\text { sted }\end{array}$ & Prove tattfra & $\begin{array}{l}\text { Cwre flater } \\
\text { front } \\
\text { pă apparter }\end{array}$ & $\begin{array}{c}\text { Cvreflater } \\
\text { bakkant pă } \\
\text { apparater }\end{array}$ & $\begin{array}{l}\text { Nedre } \\
\text { flate } \\
\text { Front pă } \\
\text { apparater }\end{array}$ & $\begin{array}{c}\text { Betjenings } \\
\text { panel } \\
\text { (loddrette } \\
\text { flater) } \\
\end{array}$ & Håndtak & Kontakt & Brytere/stanf \\
\hline \multirow{5}{*}{ 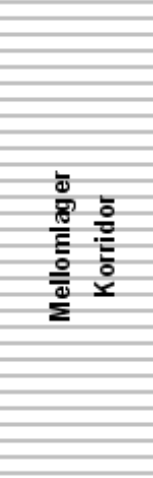 } & \begin{tabular}{|l|} 
Nr.1 \\
Utralyd \\
Generator \\
\end{tabular} & $18(8-39)$ & $19(7-60)$ & $38(18-58)$ & & $4(1-30)$ & & $3(0-6)$ \\
\hline & \begin{tabular}{|c|} 
Nr.2 \\
Ultralydgenerat \\
or \\
\end{tabular} & $13(2-37)$ & $27(9-60)$ & $22(3-110)$ & & $2(0-45)$ & & $1(0-11)$ \\
\hline & $\begin{array}{c}\text { Nr.3 } \\
\text { Ultralydgenerat } \\
\text { or } \\
\end{array}$ & $\mathbf{1 5}(1-100)$ & $16(3-25)$ & $30(6-84)$ & & $1(0-12)$ & & $0(0-9)$ \\
\hline & $\begin{array}{c}\text { Nr.4 } \\
\text { Endoskopiack }\end{array}$ & $5(0-30)$ & & $23(9-200)$ & $1(0-3)$ & $1(0-30)$ & $3(0-60)$ & \\
\hline & $\begin{array}{c}\text { Nr.5 } \\
\text { Endoskopirack }\end{array}$ & $15(7-35)$ & & $23(6-45)$ & $1(0-18)$ & $4(1-29)$ & $1(0-5)$ & \\
\hline \multirow{7}{*}{ 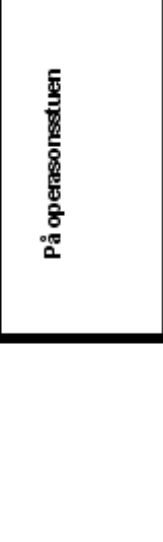 } & $\begin{array}{c}\text { Nr.6 } \\
\text { Diatermi }\end{array}$ & $4(0-13)$ & & $29(18-90)$ & $2(0-15)$ & & $3(0-17)$ & $3(015)$ \\
\hline & $\begin{array}{c}\text { Nr.7 } \\
\text { Diatemii }\end{array}$ & $16(0-33)$ & & $43(32-94)$ & $3(0-6)$ & & $1(0-8)$ & $1(0-13)$ \\
\hline & $\begin{array}{c}\text { Nr.8 } \\
\text { Endoskopirack }\end{array}$ & $23(4-65)$ & $43(0-72) *$ & $41(22-67)$ & & $0(0-25)$ & & $3(0-50)$ \\
\hline & & & & & & \begin{tabular}{|l} 
Court \\
Tactagur
\end{tabular} & \multicolumn{2}{|c|}{ 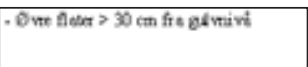 } \\
\hline & & & & & & & \multicolumn{2}{|c|}{ - Hedre fhier < $30 \mathrm{cn}$ fra gutwrivi } \\
\hline & & & & & & & \multicolumn{2}{|c|}{ Lodatte fiata $>90 \mathrm{cn}$ fro gotveri } \\
\hline & & & & & & & \multicolumn{2}{|c|}{ 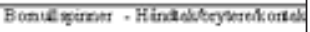 } \\
\hline
\end{tabular}

typer støvbakterier, for eksempel Bacillus subtilis. For prøvetaking med Count-Tactagar viste resultatene verdier fra 0

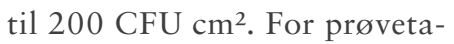
king med bomullspinner viste resultatene verdier fra 0 til 60 kolonier (tabell 1). Tabell 1 viser de fem prøvetakningspunktene for hvert apparat.

Det var vesentlig større oppvekst fra flater nært gulvnivå enn høyere oppe på apparatene (tabell 2). Størst oppvekst ble funnet fra prøver tatt fra flate på baksiden av apparat nr. 8, der det også fantes synlig støv. Der var det en gjennomsnittlig oppvekst på $85 \mathrm{CFU} / \mathrm{cm}^{2}$. Av prøver tatt fra punkter som av/på brytere, var det sparsom forekomst. Fra flater på apparatene, der ledninger lå kveilet opp (bakre del av apparatet) når apparatet ikke var i bruk, viste resultatene noe større oppvekst enn fra flater der det sjelden blir lagt ledninger (fremre del av apparatet) (tabell 1).

Prøver fra utstyr som ble lagret i korridor eller mellomlager, viste en tendens til mindre oppvekst enn fra utstyr som var plassert inne på stuene. Opplysninger om apparatenes forflytninger ble innhentet underveis, men ikke alt ble registrert. De registreringene som ble gjort, viste hvor apparatene i hovedsak sto lagret og hvor mange ganger de hadde vært i bruk i måleperioden. Apparat nr. 1, 2, 3, 4 og 
5 var ved de fleste prøvetakinger plassert i korridor eller mellomlager (tabell 1, øvre ramme). Apparat nr. 6, 7 og 8 var for det meste stasjonert på operasjonsstuene (tabell 1 , nedre ramme).

I og med at det ble benyttet to ulike prøvetakingsmetoder, er måleverdiene gruppert med forskjellige fargekoder ut fra metoden som er benyttet (tabell 1,2). Resultatene er fremstilt i median. I tabellen er resultatene der agarskåler er benyttet oppgitt $\mathrm{i}$ antall $\mathrm{CFU} \mathrm{cm}^{2}$, og der bomullspinner er benyttet er mengden oppgitt i antall kolonier.

Mikrobetall målt på utstyr lagret utenfor stuene, viste en tendens til å være lavere enn på utstyr oppbevart inne på stuene. Mengden oppvekst var størst fra prøver tatt av flater lengst ned mot gulvnivå og på baksiden av apparatene. Prøver som ble tatt fra av/på brytere viste liten grad av bakterieoppvekst. Resultatet fra prøvene tatt av det mobile utstyret viste generelt liten forekomst av bakterier.

\section{DISKUSJON}

Selv om registreringen av bevegelsene av apparatene ikke ble optimalt gjennomført, mener vi ut ifra det som ble registret, å kunne se et mønster i forflytningene av apparatene sett i forhold til måleresultatene. Resultatene viste at mobilt medisinsk teknisk utstyr oppbevart i korridor ikke var mer utsatt for bakteriologisk kontaminasjon enn tilsvarende stasjonært utstyr. Dette kan kanskje forklares med at apparatene som var lagret på mellomlager eller korridor viste seg å være relativt godt beskyttet. Disse områdene var tilbaketrukket fra aktivitet som medfører stort nedslag av mikroorganismer. Mellomlager eller korridor alle sider av apparatene.

Resultatene viste mer oppvekst fra prøver fra baksiden av apparatene enn fra forsiden. Det ansees som uheldig at det er store funn selv om det er bakpå apparatene. Mikroorganismer i støvlaget vil lett kunne virvles opp i luften ved høy aktivitet og medføre fare for smittespredning. Resultatene viste også liten forekomst av bakterier på brytere og håndtak, noe som kan være et resultat av god

\section{Provene viste generell liten forekomst 2 av bakterier.}

ble ikke brukt til lager for urene artikler, noe som kan forsvare lagringsplassene som gode nok. Prøver tatt fra utstyr som ble stående på stuen hadde en tendens til større oppvekst. Årsaker til dette kan være at aktiviteten inne på operasjonsstuen er høyere enn i mellomlager eller korridor, med flere personer til stede. I tillegg er arealet mer begrenset. Dette kan føre til flere bakterier i lufta som kan forurense utstyret. Samtidig er det mulig at utstyr som skal kjøres ut av stuen etter bruk, blir bedre rengjort. På stuer med liten plass for bevegelse, vil dette resultere $i$ at det blir mer tungvint å flytte utstyr for å foreta rengjøring på

TABELL 2: Mengde oppvekst mikrobiologiske prøver tatt fra ulike nivå og prøvetakingsplasser ved av mobilt medisinsk teknisk utstyr. * Oppvekst fra bomullspinne er angitt i antall kolonier (mean/median/range), de øvrige fra agar i CFU/cm²

\begin{tabular}{llll}
\hline Mengde oppvekst & Mean & Median & Range \\
Øvre flater, agar (11 prøvepunkt) & 17 & 16 & $1-100$ \\
Nedre flater, agar (9 prøvepunkt) & 38 & 30 & $0-200$ \\
$\begin{array}{l}\text { Betjeningspanel på loddrette flate, } \\
\text { agar (4 prøvepunkt) }\end{array}$ & 3 & 1 & $0-18$ \\
\begin{tabular}{l} 
Håndtak, brytere, pinne (16 prøvepunkt) \\
\hline
\end{tabular}
\end{tabular}

og disiplinert håndhygiene av brukerne, eller at rengjøringsrutinene på disse punktene er tilfredsstillende. Rengjøring på brytere og knapper er svært viktig med hensyn til spredning av bakterier og infeksjonsrisiko, da bakterier lett overføres ved berøring og indirekte kontaktsmitte.

Etter bruk er det på enkelte apparater, av mangel på mer egnete plasser, mest hensiktsmessig å plassere oppkveilede ledninger og annet utstyr på flater oppå apparatet. På tross av at det er i strid med hygieniske prinsipper. Prøvene tatt fra disse punktene, viste også at det var større oppvekst der ledninger hadde ligget på øvre flate (bakre del) enn der (fremre del) det ikke hadde ligget ledninger. At resultatene viste gjennomgående lavere mikrobefunn fra prøver tatt fra høyere nivå, var som forventet ut ifra tidligere studier (12).

Luftkvaliteten kan være med på å påvirke mikrobeforekomst på medisinsk teknisk utstyr, men det ble ikke tatt luftprøver i dette studiet. Prøvetaking ble utført før operasjonsstuer og 
apparater ble benyttet de aktuelle dager. Annen type aktivitet fra forrige prøvetaking ble ikke registrert, derfor er det vanskelig å si noe om hvorvidt aktivitet kan ha påført apparatet forurensing.

Dyrkningsresultatene fra de ulike prøvene, var hovedsakelig ulike typer hvite stafylokokker. Disse funnene i seg selv er ikke spesielle. Men de viser at smitte via medisinsk teknisk utstyr er meget aktuelt. Det er i dette prosjektet hovedsakelig fokusert på bakteriell kontaminasjon, så mulige andre mikroorganismer er ikke undersøkt.

Metoden som ble benyttet for prøvetaking, ble valgt ut fra muligheten til å etablere en gjennomførbar metode som var enkel å reprodusere. Prøvetakingen ga mulighet til å se grad av bakteriell kontaminasjon og forekomst av ulike typer bakterier. Agarmetoden ga nøyaktige $\mathrm{CFU} / \mathrm{m}^{2}$, mens prøvetaking med bomullspinne ikke er en kvantitativ metode. Metoden er ikke så lett å standardisere når det gjelder prøvearealet og prøvemengden som dyrkes. Da alle prøvetakinger ble gjennomført av samme person og det ble utført relativt mange prøvetakinger, vurderes resultatet fra de to metodene som sammenlignbare.

For å redusere antall postoperative infeksjoner i sykehus er det viktig at kontaminering av utstyr reduseres både i den operative fasen og at utstyr som brukes ved kirurgiske inngrep er minst mulig belastet med bakterier (1). Økt kunnskap om risikofaktorer i forhold til postoperative sårinfeksjoner er viktig, noe som kan gi helsepersonell mulighet til å redusere infeksjonsforekomsten (12).

\section{KONKLUSJON}

Mobilt medisinsk teknisk utstyr oppbevart i korridor, var ikke mer utsatt for bakteriologisk kontaminasjon enn tilsvarende stasjonært utstyr. Dette kan ha betydning for valg av oppbevaringssted for medisinsk teknisk utstyr i en operasjonsavdeling.
Mengde oppvekst var størst fra prøver tatt av flater nederst mot gulvnivå og på baksiden av apparatene. Prøver som ble tatt fra av/på knapper samt betjeningspanel viste liten grad av bakterieoppvekst.

Resultatet fra prøvene tatt av det mobile utstyret viste generelt liten forekomst av bakterier. Funnene av patogene bakterier var i hovedsak hvite stafylokokker som ikke regnes som spesielt patogene i denne sammenheng.

Resultatene oppfordrer til en bevisstgjøring rundt rengjøring og plassering av mobilt medisinsk teknisk utstyr og dens tilbehør. Det viser også at det er viktig at det med jevne tidsintervall foretas en slik prøvetaking. Ved de fleste sykehus finnes ikke slike rutiner. Vi mener med denne studien å ha tilført litt mer kunnskap om kontaminering av mobilt medisinteknisk utstyr brukt ved kirurgiske inngrep, noe som også kan komme pasientene til gode. Videre forskning på dette området vil være nyttig.

\section{REFERANSER}

1. Andersen B.M. Håndbok i hygiene og smittevern for sykehus. Mikrober og smitteveier. Ullevål universitetssykehus HF, 2008.

2. Nasjonal ROS - og beredskapsanalyse innen helse. Delrapport. Safetec på oppdrag fra: Sosial- og helsedirektoratet, 2. mai 2005. Tilgjengelig fra: http://www.shdir.no/vp/ multimedia/archive/00003/Delrapport_biologisk_3153a.doc

3. Helse-og omsorgsdepartementet: Handlingsplan for å forebygge sykehusinfeksjoner 2004-2006.

4. Rettleiar til forskrift om smittevern i helsetenesta. Smittevern 15. Nasjonalt folkehelseinstitutt, juni 2006.

5. Nasjonal strategi for forebygging av infeksjoner i helsetjenesten og antibiotikaresistens (2008-2012). Helse-og omsorgsdepartementet, 2008. Til- gjengelig fra: http://www.regjeringen. no/upload/HOD/Dokumenter\%20FHA/ Nasjonal\%20strategi\%20infeksjonerantibiotikaresistens.pdf

6. Kvam A, Jacobsen T. Bakterieflora fra gulv til pasient? Sykepleien. 2002 90 (20):

39-41

7. Schøyen R. Mikroorganismer og sykdom, Gyldendal Norsk Forlag AS, Oslo 2004.

8. Hovig B, Lystad A. Infeksjonssykdommer - epidemiologi, mikrobiologi og smittevern, Gyldendal Norsk Forlag AS, Oslo 2001.

9. Statens helsetilsyn. Retningslinjer for mikrobiologisk kontroll av luft i rom hvor det foretas operative inngrep og større invasive prosedyrer (operasjonsrom). Rundskriv-IK-02/97. Saksnr.97/31.18.04.1997.

10. Ventilasjon av operasjonsstuer.
Sintef rapport 78A014005. 08052001 11. Manual Count-Tact agar (CT). For the monitoring of biocontamination of surfaces in hospital and industrial environments. BioMerieux, 08470 E-GB-2004/05.

12. Att förebygga vårdrelaterte infektioner - et kunnskapsunderlag. Socialstyrelsen i Sverige. Edita Västre Aros. ISBN:91-85482-14-5/2006.

13. Brattheim B, Kvam A. Kartlegging av mikrobiologisk kontaminasjon på operasjonsstuer. FoU-prosjekt. Høyskolen i Sør-Trøndelag (HIST) og St. Olavs Hospital. Prosjektrapport 2008. 14. Kvam A, Brattheim B, Vutudal V. Bakterienivået i lufta i "Fremtidens operasjonsrom" Bioingeniøren 8.2008;6-10.

Les kommentaren på side 123 》 